\title{
Intestinal pH profile in rainbow trout Oncorhynchus mykiss and microhabitat preference of the flagellate Spironucleus salmonis (Diplomonadida)
}

\author{
M. Reza Saghari Fard ${ }^{1,2, *}$, Claudia Weisheit ${ }^{1,2}$, Sarah L. Poynton ${ }^{2,3}$ \\ ${ }^{1}$ College of Agriculture and Horticulture, Humboldt University of Berlin, Invalidenstrasse 42, 10115 Berlin, Germany \\ ${ }^{2}$ Department of Inland Fisheries, Leibniz-Institute of Freshwater Ecology and Inland Fisheries, Müggelseedamm 310, \\ 12587 Berlin, Germany \\ ${ }^{3}$ Department of Molecular and Comparative Pathobiology, Johns Hopkins University School of Medicine, 733 \\ North Broadway, Room 807, Baltimore, Maryland 21205-2196, USA
}

\begin{abstract}
In farmed rainbow trout Oncorhynchus mykiss, the flagellate Spironucleus salmonis (Diplomonadida) is often found in the pyloric region of the intestine. While previous in vitro studies report a pH of 7.5 to 8.0 as optimal for presumed $S$. salmonis, no previous in vivo studies have investigated the relationship between $\mathrm{pH}$ and microhabitat preference. Therefore, in 698 rainbow trout ( $75 \%$ were 5 to 6 mo old juveniles, 10 to $20 \mathrm{~cm}$ total length), we recorded occurrence and density of $S$. salmonis, and $\mathrm{pH}$, in the pyloric, anterior, middle, and posterior intestine. There were no significant differences in total length or weight between infected and uninfected fish. S. salmonis preferred the pyloric region, with occurrence and density decreasing significantly from pyloric to posterior regions. In infected fish, $\mathrm{pH}$ in pyloric (6.8 to 7.9 , mean 7.3 ) and posterior regions $(6.5$ to 8.0 , mean 7.1 ) was significantly lower than in anterior (6.5 to 8.5, mean 7.7) and middle (6.8 to 8.2, mean 7.7) regions; in uninfected fish, the pH profile was similar. At the individual level, $90 \%$ of infected fish and $79 \%$ of uninfected fish showed this $\mathrm{pH}$ profile. In the pyloric region, $\mathrm{pH}$ was not significantly different among uninfected fish, and fish with light, moderate, or heavy infections. Our in vivo study suggests the optimal pH for $S$. salmonis is between 7.1 and 7.5, possibly close to 7.3 (the mean in pyloric region of infected fish). We conclude that while the presence of $S$. salmonis reflected tolerable pH, density of infection was not correlated with $\mathrm{pH}$, and thus a causal relationship between microhabitat preference and $\mathrm{pH}$ is unlikely.
\end{abstract}

KEY WORDS: Diplomonad flagellate - Intestinal tract $\cdot$ Microhabitat preference $\cdot$ Oncoryhnchus mykiss $\cdot \mathrm{pH}$ profile $\cdot$ Rainbow trout $\cdot$ Spironucleus salmonis

\section{INTRODUCTION}

Diplomonad flagellates can cause intestinal and systemic infection, with significant morbidity and mortality in aquaculture (Woo \& Poynton 1995). Despite their economic importance, many aspects of hostdiplomonad interactions, including microhabitat preference, are not well understood. Different species of piscine diplomonads have different microhabitat pref- erences (Table 1), and among the enteric species, Spironucleus salmonis, S. torosa, and S. vortens prefer the pyloric region, rectum, and middle intestine, respectively (Moore 1922a,b, Davis 1926, Ferguson 1979, Poynton \& Morrison 1990, Poynton et al. 1995, 2004, Sterud 1998a,b). These preferences may reflect adaptions to the variations in morphology, physiology and metabolic gradients in the fish intestine (see Weinreb \& Bilstad 1955, Anderson \& Mitchum 1974). 
Table 1. Spironucleus spp. Microhabitat preferences of well-characterised piscine diplomonads. A: aquaculture; D: anadromous; F: freshwater; S: seawater; W: wild

\begin{tabular}{|c|c|c|c|c|c|}
\hline Species & Host & Locations & \multicolumn{2}{|c|}{ Geographic locality } & Source \\
\hline S. barkhanus & $\begin{array}{l}\text { Arctic char } \\
\text { Grayling }\end{array}$ & $\begin{array}{l}\text { Intestine, gall bladder } \\
\text { Intestine, gall bladder }\end{array}$ & $\begin{array}{l}\text { W,D } \\
\text { W,F }\end{array}$ & $\begin{array}{l}\text { Norway } \\
\text { Norway }\end{array}$ & $\begin{array}{l}\text { Sterud et al. (1998) } \\
\text { Sterud et al. (1997) }\end{array}$ \\
\hline S. salmonicida ${ }^{\mathrm{a}}$ & $\begin{array}{l}\text { Arctic char } \\
\text { Atlantic salmon } \\
\text { Chinook salmon }\end{array}$ & $\begin{array}{l}\text { Systemic (intracellular) } \\
\text { Systemic } \\
\text { Systemic }\end{array}$ & $\begin{array}{l}\mathrm{A}, \mathrm{S} \\
\mathrm{A}, \mathrm{S} \\
\mathrm{A}, \mathrm{S}\end{array}$ & $\begin{array}{l}\text { Norway } \\
\text { Norway } \\
\text { Canada }\end{array}$ & $\begin{array}{l}\text { Sterud et al. (2003) } \\
\text { Sterud et al. (1997, 1998) } \\
\text { Kent et al. (1992) }\end{array}$ \\
\hline S. salmonis ${ }^{\mathrm{b}}$ & $\begin{array}{l}\text { Brook trout } \\
\text { Brown trout } \\
\text { Lake trout } \\
\text { Rainbow trout } \\
\text { Rainbow trout }\end{array}$ & $\begin{array}{l}\text { Intestine (pyloric) } \\
\text { Intestine (pyloric) } \\
\text { Intestine (pyloric) } \\
\text { Intestine (pyloric) } \\
\text { Intestine (pyloric) }\end{array}$ & $\begin{array}{l}\mathrm{A}, \mathrm{F} \\
\mathrm{A}, \mathrm{F} \\
\mathrm{A}, \mathrm{F} \\
\mathrm{A}, \mathrm{F} \\
\mathrm{A}, \mathrm{F}\end{array}$ & $\begin{array}{l}\text { USA } \\
\text { USA } \\
\text { USA } \\
\text { USA } \\
\text { Ireland }\end{array}$ & $\begin{array}{l}\text { Moore (1922a,b) } \\
\text { Davis (1926) } \\
\text { Ferguson (1979) } \\
\text { Poynton et al. }(2004)\end{array}$ \\
\hline S. torosa & $\begin{array}{l}\text { Burbot } \\
\text { Cod } \\
\text { Cod } \\
\text { Haddock } \\
\text { Saithe }\end{array}$ & $\begin{array}{l}\text { Intestine (rectum) } \\
\text { Intestine (rectum) } \\
\text { Intestine (rectum) } \\
\text { Intestine (rectum) } \\
\text { Intestine (rectum) }\end{array}$ & $\begin{array}{l}\text { W,F } \\
\text { W,S } \\
\text { W,S } \\
\text { W,S } \\
\text { W,S }\end{array}$ & $\begin{array}{l}\text { Norway } \\
\text { Norway } \\
\text { Canada } \\
\text { Canada } \\
\text { Norway }\end{array}$ & $\begin{array}{l}\text { Sterud (1998a) } \\
\text { Sterud (1998b) } \\
\text { Poynton \& Morrison (1990) } \\
\text { Poynton \& Morrison (1990) } \\
\text { Sterud (1998b) }\end{array}$ \\
\hline S. vortens & $\begin{array}{l}\text { Angelfish } \\
\text { Angelfish } \\
\text { Discus }\end{array}$ & $\begin{array}{l}\text { Intestine (middle), lip tumor } \\
\text { Intestine, head lesions } \\
\text { Systemic }\end{array}$ & $\begin{array}{l}\mathrm{A}, \mathrm{F} \\
\mathrm{A}, \mathrm{F} \\
\mathrm{A}, \mathrm{F}\end{array}$ & $\begin{array}{l}\text { USA } \\
\text { UK } \\
\text { UK }\end{array}$ & $\begin{array}{l}\text { Poynton et al. (1995) } \\
\text { Paull \& Matthews (2001) } \\
\text { Paull \& Matthews (2001) }\end{array}$ \\
\hline
\end{tabular}

The concentration of diplomonads in the pyloric region of trout is likely to be predominantly due to physiological and metabolic factors, rather than morphology, since the one valve between the intestine and the rectum is indistinct (Ezeasor \& Stokoe 1980). Both $\mathrm{pH}$ and bile have been suggested to play decisive roles in determining the microhabitat preference of diplomonads in trout (Buchmann \& Uldal 1996, Uldal \& Buchmann 1996). This suggestion is based on in vitro studies showing a pH tolerance of 5 to 10 (optimum 7.5 to 8.0), and that bile in low concentrations (30 to $960 \mathrm{mg} \mathrm{l}^{-1}$ ) enhanced flagellate propagation slightly. However, there are no in vivo studies that test this hypothesis, or any other hypothesis about factors determining microhabitat preference in piscine diplomonads.

In the present study, we therefore investigated in vivo the role of $\mathrm{pH}$ in microhabitat preference of Spironucleus salmonis in the intestinal tract of rainbow trout. The simple intestinal tract in trout comprises a short cranial ascending limb bearing pyloric caecae, and a longer caudal descending limb (intestine) extending to a distinct rectum with annulo-spiral septa arranged as a stack of caudally directed funnels (Anderson \& Mitchum 1974, Ezeasor \& Stokoe 1980, Smith 1989, Willers 1991). In our studies we divided the intestinal tract into 4 regions, consistent with previous studies by Uldal \& Buchmann (1996).
We approached our investigations by posing 6 main questions: (1) what is the occurrence of infection (presence/absence) in different intestinal regions; (2) what is the density of infection in different intestinal regions, and what is the relationship between density of infection in the pyloric region and that in each of the 3 downstream intestinal regions; (3) what is the $\mathrm{pH}$ in different intestinal regions in uninfected fish; (4) what is the $\mathrm{pH}$ in different intestinal regions in infected fish; (5) what is the difference between the $\mathrm{pH}$ in uninfected and infected fish per intestinal region; and (6) what is the relationship between the $\mathrm{pH}$ and density of infection in different intestinal regions?

We also used our data set to investigate 2 further questions: (7) what is the relationship between size of fish and infection; and (8) what is the relationship between size of fish and $\mathrm{pH}$ ?

\section{MATERIALS AND METHODS}

Experimental design. New data were collected on occurrence and density of diplomonad infection in rainbow trout, along with concurrent measurement of $\mathrm{pH}$ conditions in the same fish in order to allow comparison of these parameters.

Source and size of fish. A total of 698 juvenile rainbow trout were collected during summer and winter 
between 2001 and 2005 from Seltershof farm near Berlin, Germany $\left(52.061^{\circ} \mathrm{N}, 12.884^{\circ} \mathrm{E}\right)$, where they had been fed with Skretting Classic trout food (Skretting). After transport to the laboratory, the fish were held in an indoor flow-through system, supplied with tap water at 9 to $11^{\circ} \mathrm{C}$, and fed 3 times $\mathrm{d}^{-1}$ with Forellenmastfutter FM 49/22 EXSP (1.8 mm) (Aquavalent).

At the time of examination, the total length of fish ranged from 5.5 to $22.5 \mathrm{~cm}$ (mean 12.7, $\mathrm{SD} \pm 3.5$ ), and their weight ranged from 1.4 to $113.0 \mathrm{~g}$ (mean 26.8, $\mathrm{SD} \pm 23.7$ ); we estimate our fish were 3 to 7 mo old (since the farm frequently graded the fish, no exact age was available). Although there was a large size range of fish, most ( $75 \%$ ) were 10 to $20 \mathrm{~cm}$ total length (5 to 6 mo old juveniles), and the mean total length ranged from 11.5 to $12.7 \mathrm{~cm}$ in 4 of 5 data sets.

Examination of fish, quantifying infection, and recording $\mathbf{p H}$. Only $5 \%$ of fishes were examined the day of collection. The remaining $95 \%$ were examined within 4 wk of collection, by which time they should have acclimated to the holding conditions in the laboratory. Similar numbers of fish were examined in each of the $4 \mathrm{wk}$ after collection. The time interval between feeding and examination varied from 0.5 to $5.0 \mathrm{~h}$.

The intestine was divided into 4 regions, as suggested by Uldal \& Buchmann (1996), viz. pyloric region (ascending intestine bearing pyloric caecae), anterior (anterior $1 / 3$ of length from anterior descending intestine to anus, and comprising only descending intestine), middle (middle $1 / 3$ of length from anterior descending intestine to anus, comprising descending intestine and part of rectum), and posterior (posterior $1 / 3$ of length from descending intestine to anus, comprising rectum only).

For each region, occurrence (presence or absence) of diplomonads was recorded. Density was semi-quantitatively estimated as the number of flagellates under a $22 \times 22 \mathrm{~mm}$ cover slip (484 $\left.\mathrm{mm}^{2}\right)$ ( $\mathrm{n}=1$ to 3 per fish). We considered light infection (1+) as less than 10 flagellates/484 $\mathrm{mm}^{2}$, moderate infection $(2+)$ as 11 to 40 flagellates $/ 484 \mathrm{~mm}^{2}$, and heavy infection (3+) as $>40$ flagellates/484 $\mathrm{mm}^{2}$ (Saghari Fard 2001).

The $\mathrm{pH}$ of the intestinal contents was recorded with an accuracy of 0.2 by using $\mathrm{pH}$ indicator strips $(\mathrm{pH}$ Indikatorstäbchen: VWR 1.09543.0001) (VWR International). After the samples of intestinal contents had been taken for determining occurrence and density of diplomonads, a pH strip was laid tangentially in each of the 4 regions (hence 4 strips per fish), and gently pressed into the remaining intestinal contents. After a few minutes (allowing for maximum colour change), the strips were removed, and the $\mathrm{pH}$ was determined against a reference strip.

The pH was recorded in 37 uninfected fish, in 21 infected fish with Spironucleus salmonis present in all
4 intestinal regions, and in 65 fish with $S$. salmonis present in only 1, 2 or 3 regions of the intestine.

Identification of the diplomonad. We confirmed the identification of the diplomonad as Spironucleus salmonis based on our previous ultrastructural studies and molecular characterisation (Fard et al. 2007).

Statistical analysis. Our analysis began by using the Kolmogorov-Smirnov (K-S) test to determine whether data were normally distributed. Levene's test was used to determine homogeneity of the variance.

For the 6 main questions in our study, the $\chi^{2}$ test was used to test for differences in occurrence and density of infection between intestinal regions (Questions 1 and 2), (the test was performed on the number of fish, not the percentage, and for density, we compared the proportions of infections that were light, moderate or heavy pairwise between regions). The Mann-Whitney test was used to determine the relationship between density of infection in the pyloric region and that in each of the 3 downstream intestinal regions (Question 2). One-way ANOVA was used to test the significance of differences in $\mathrm{pH}$ between the intestinal regions in uninfected and infected fish (Questions 3 and 4, respectively), followed by Tukey's honestly significant difference (HSD) test to compare regions pairwise. The $t$-test was used for comparing the $\mathrm{pH}$ in uninfected and infected fish per region (Question 5). The Kruskal-Wallis test (for non-normally distributed data) was used to test for significant differences in $\mathrm{pH}$ in the pyloric region between uninfected, lightly, moderately, and heavily infected fish (Question 6).

For the 2 supplementary questions, the Mann-Whitney test (for non-normally distributed data) was used to test for significant differences in size (total length and weight) between uninfected and infected fish (Question 7). Pearson's correlation coefficients were used to test the relationship between size of fish (total length and weight for 37 uninfected fish) and $\mathrm{pH}$ in each intestinal region (Question 8).

All statistical tests were done using SPSS (version 9), and the results were considered significant if $\mathrm{p}<0.05$.

\section{RESULTS \\ Overview}

Both occurrence and density of Spironucleus salmonis differed significantly along the length of the intestine, being highest in the pyloric region and then decreasing posteriorly. The $\mathrm{pH}$ profile in uninfected and infected fish was characterized by more neutral conditions in the pyloric and posterior regions, and significantly more alkaline conditions in the anterior and 
middle regions of the intestine. In the pyloric region, the $\mathrm{pH}$ was not significantly different in uninfected and lightly, moderately and heavily infected fish.

Among the 698 fish examined, 168 were infected (prevalence of infection $24 \%$ ). There was no significant difference in size of infected and uninfected fish. Furthermore, there was no significant correlation between size of fish and $\mathrm{pH}$ in any of the 4 intestinal regions.

\section{Occurrence of infection and region}

The occurrence of Spironucleus salmonis was significantly higher in the pyloric region $(24 \%$ of fish were infected in this site) than in each of the other 3 regions (anterior $15 \%$, middle $13 \%$ and posterior $10 \%)\left(\chi^{2}, \mathrm{p}<\right.$ 0.001 ), and the occurrence in the anterior region was also significantly higher than in the posterior region $\left(\chi^{2}, p<0.005\right)$ (Fig. 1).

\section{Density of infection and region}

The density of Spironucleus salmonis in the pyloric region was significantly higher than in the anterior, middle and posterior regions $\left(\chi^{2}, \mathrm{p}<0.0001\right)$, and density in the anterior region of the intestine was also significantly higher than in the middle and posterior regions $\left(\chi^{2}, \mathrm{p}<0.05, \mathrm{p}<0.005\right.$ respectively). Results for 3 categories of density (upon which the $\chi^{2}$ tests were based) per intestinal region are shown in Fig. 1.

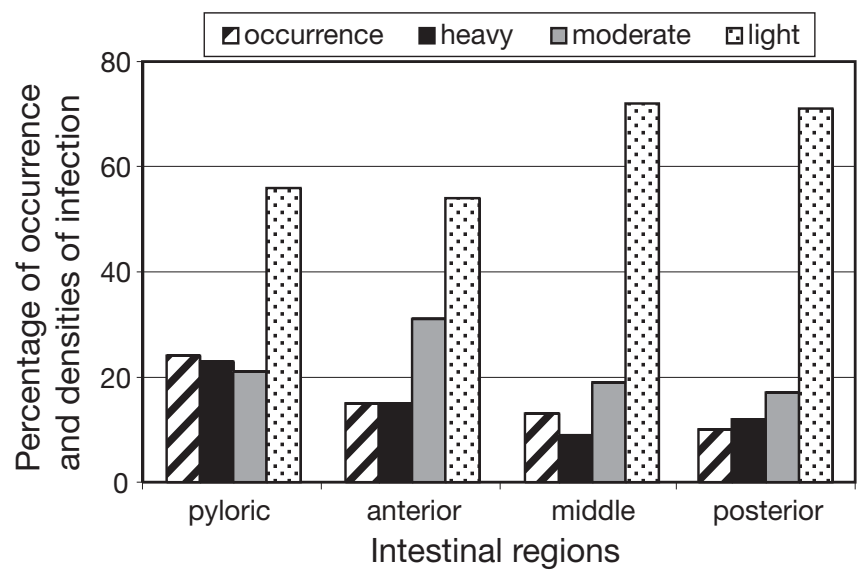

Fig. 1. Spironucleus salmonis infecting Oncorhynchus mykiss. Occurrence and density of the diplomonads in each of 4 regions of the intestinal tract of juvenile rainbow trout. Occurrence expressed as percentage of infected fish per region $(\mathrm{n}=$ 698 fish for each region). Densities expressed as percentage of infected fish with each density per region $(n=168$ fish for pyloric region, $\mathrm{n}=105$ fish for anterior region, $\mathrm{n}=89$ fish for middle region, and $n=69$ fish for posterior region)
In 38 fish heavily infected in the pyloric region, the density of infection in each of the 3 downstream intestinal regions was significantly higher than that in the 94 fish lightly infected in the pyloric region (MannWhitney test, $\mathrm{p}<0.0001$ ). Furthermore, in $100 \%$ of fish heavily infected in the pyloric region, all 3 downstream regions were infected, whereas there were no fish infected in all 3 downstream regions when the pyloric region was lightly infected.

\section{$\mathrm{pH}$ and region in uninfected fish}

Along the length of the intestine of 37 uninfected fish, $\mathrm{pH}$ ranged from 6.7 to $8.2(\mathrm{n}=37)$ (Table 2$)$. The $\mathrm{pH}$ was significantly lower in the pyloric and posterior regions than in the anterior and middle regions $\left(\right.$ ANOVA, $\left.F_{(3,144)}=15.97, \mathrm{p}<0.0001\right)($ Table 2$)$ (Fig. 2).

At the individual level, among 37 uninfected fish, $79 \%$ adhered to this $\mathrm{pH}$ profile (defined as more neutral, more alkaline, more alkaline, more neutral, for pyloric, anterior, middle, and posterior regions, respectively).

\section{$\mathrm{pH}$ and region in infected fish}

Along the length of the intestine of 21 fish that were infected in all regions of the intestinal tract, $\mathrm{pH}$ ranged from 6.5 to 8.5 (Table 2). The $\mathrm{pH}$ was significantly lower in the pyloric and posterior regions than in the anterior and middle regions (ANOVA, $F_{(3,80)}=3.711$, $\mathrm{p}<0.05$ ) (Table 2) (Fig. 2).

At the individual level, among 21 infected fish, 90\% adhered to this $\mathrm{pH}$ profile (more neutral, more alkaline, more alkaline, more neutral).

\section{pH in uninfected and infected fish per region}

There were no significant differences in $\mathrm{pH}$ between 37 uninfected and 21 infected fish in the pyloric, anterior and middle regions; however, in the posterior region, the $\mathrm{pH}$ was significantly more alkaline in uninfected fish than in infected fish $(t$-test, $t(56)=-2.58, \mathrm{p}<0.05)$ (Table 2$)$.

\section{$\mathrm{pH}$ and density of infection in different regions}

In the pyloric region, there were no significant differences in $\mathrm{pH}$ between the 37 uninfected fish, 22 lightly, 22 moderately, and 21 heavily infected fish (Table 2). The low number of fish with moderate and heavy infections in anterior, middle and posterior regions precluded statistical analysis (Table 2). 
Table 2. Oncorhynchus mykiss. pH in 4 different intestinal regions of uninfected and Spironucleus salmonis-infected juvenile rainbow trout. -: mean and SD not available, as $\mathrm{n}=1$

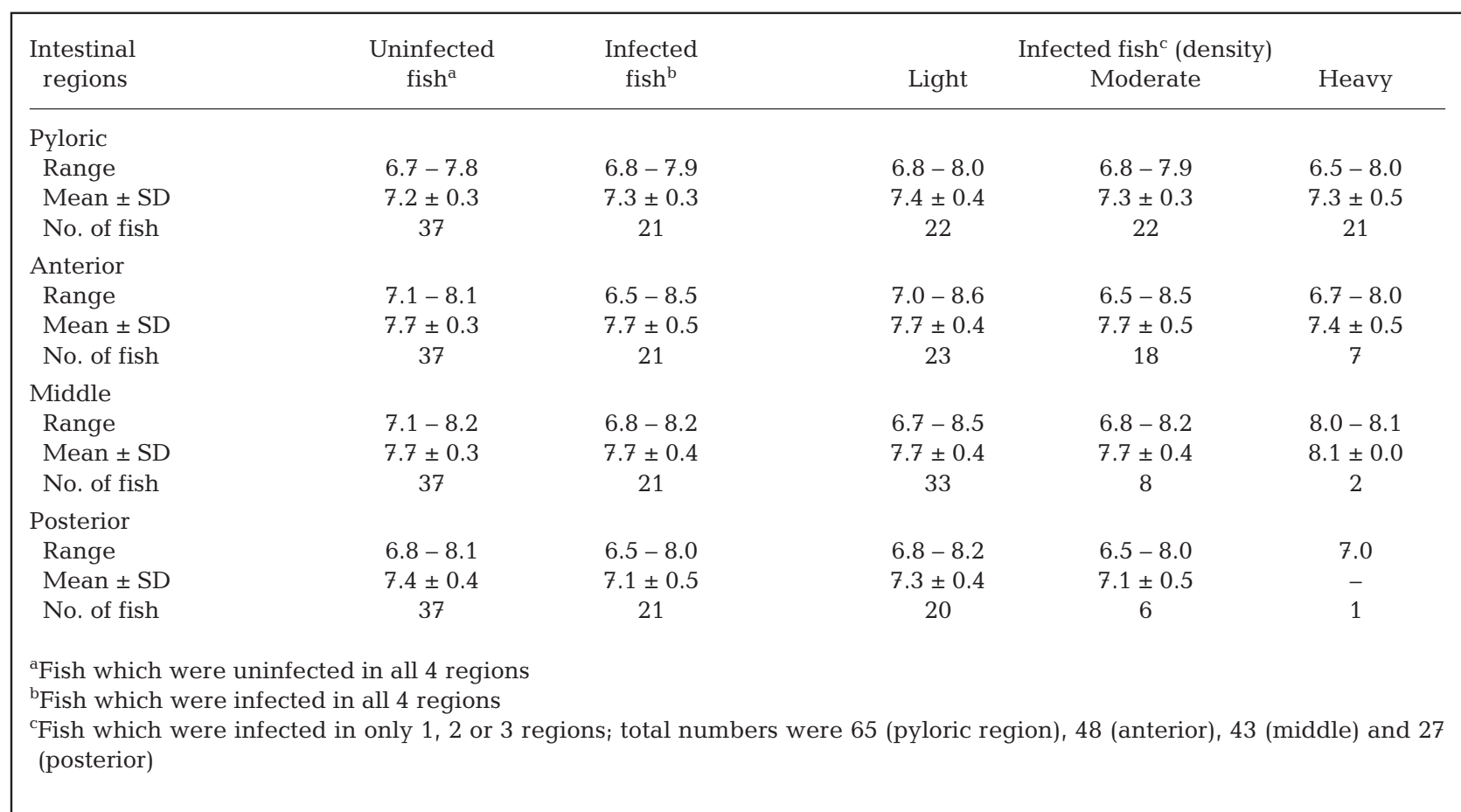

\section{Size of fish and infection}

Among the 698 fish, there was no significant difference in total length or weight between 530 uninfected fish and 168 infected fish.

\section{Size of fish and pH}

In 37 uninfected fish, there were no significant correlations between size of the fish (total length or weight) and $\mathrm{pH}$, in any of the 4 intestinal regions.

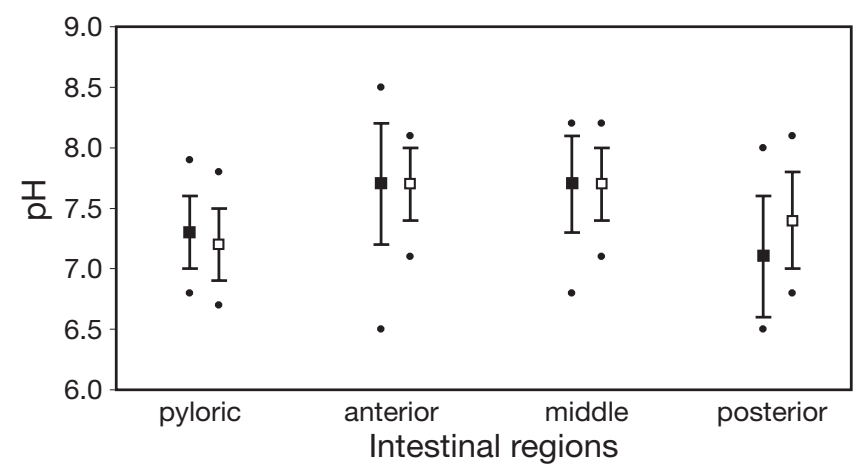

Fig. 2. Oncorhynchus mykiss. Mean $\mathrm{pH} \pm \mathrm{SD}$ in each of 4 regions of the intestinal tract of 37 uninfected $(\square)$, and 21 infected $(\mathbf{\square})$ rainbow trout with infection in all 4 regions of the intestine. $\bullet$ : $\mathrm{pH}$ range

\section{DISCUSSION}

\section{Microhabitat preference}

Spironucleus salmonis, though found throughout the intestinal tract of juvenile rainbow trout, was concentrated in the pyloric region, with both occurrence and density significantly decreasing posteriorly. This distribution was consistent with previous studies by Davis (1926), Ferguson (1979), and Moore (1922a,b), and contrasted in part with the study by Uldal \& Buchmann (1996), which did not report significant differences in occurrence and density between the pyloric and anterior regions. These differences may be due to the sizes of fish, viz. juveniles in our study (mean length $12.7 \mathrm{~cm}$ ) and fry in the study by Uldal \& Buchmann (op. cit.) (mean length $4.1 \mathrm{~cm}$ ).

The microhabitat preference in Spironucleus salmonis can initially help diagnosis of the flagellate, since the 4 other well characterized Spironucleus species have other site preferences (Table 1).

\section{pH profile in uninfected fish}

The $\mathrm{pH}$ in the intestinal tract of uninfected trout in the present study, 6.7 to 8.2 , partly overlapped the range of 7.0 to 9.0 previously reported for salmonids 
(Steffens 1989). Along the intestinal tract, we observed a distinct variation in $\mathrm{pH}$ (hereafter referred to as the $\mathrm{pH}$ profile), with means of 7.2, 7.7, 7.7 and 7.4 in the pyloric, anterior, middle and posterior regions, respectively. Longitudinal $\mathrm{pH}$ profiles have been reported for other fish with stomachs, including other salmonids, channel catfish Ictalurus punctatus, Mozambique tilapia Oreochromis mossambicus, and sea bream Sparus aurata (Page et al. 1976, Maier \& Tullis 1984).

The longitudinal $\mathrm{pH}$ profile in the juvenile rainbow trout reflects the diverse digestive processes and dietary physiology in the different regions. In the pyloric region, the acidic chyme from the stomach is mixed with bile and pancreatic secretions including zymogens and bicarbonate buffering compounds, and the $\mathrm{pH}$ becomes more neutral. The anterior and middle intestine are part of the descending intestine, having similar anatomy, physiology, and $\mathrm{pH}$. Here conditions become more alkaline as buffering decreases. In the posterior intestine, conditions become more neutral.

The wide variations in $\mathrm{pH}$ within regions of the intestinal tract of the rainbow trout (Table 2) might be explained by differences in the time interval between feeding and examination, since $\mathrm{pH}$ varies as a function of feeding time (Maier \& Tullis 1984, Deguara et al. 2003).

\section{Possible factors affecting microhabitat preference}

The range of $\mathrm{pH}$ along the intestinal tract of uninfected fish, 6.7 to 8.2 , lay well within the rather broad $\mathrm{pH}$ tolerance of 5.5 to 9.0 previously reported for putative Spironucleus salmonis in culture (Buchmann \& Uldal 1996). Thus, it is not surprising that the trophozoites were present in all 4 regions of the intestinal tract. We also note that the $\mathrm{pH}$ conditions in infected fish, 6.5 to 8.5 , were close to the $\mathrm{pH}$ conditions of 6.5 to 7.0 and 7.5 to 8.0 (the latter being most suitable) that supported population growth of putative $S$. salmonis in culture (Buchmann \& Uldal 1996). However, the pH in the preferred pyloric region (mean $\pm \mathrm{SD}$ : $7.2 \pm 0.3$ in uninfected fish, $7.3 \pm 0.3$ in infected fish) was lower than the reported optimum for putative $S$. salmonis in culture (7.5 to 8.0) (see discussion below on optimum $\mathrm{pH}$ for $S$. salmonis).

The highest numbers of Spironucleus salmonis flagellates were seen in the near neutral conditions of the pyloric region (mean $\mathrm{pH}$ 7.3), and the lowest numbers were seen in the near neutral conditions of the posterior region (mean $\mathrm{pH}$ 7.1). This distribution might be explained by the more alkaline $\mathrm{pH}$ of the anterior and middle regions of the intestine (mean $\mathrm{pH} 7.7$ for both), being less favourable for the diplomonads, reducing occurrence and density in these regions, and allowing few diplomonads to pass to the posterior region. How- ever, data from an in vitro study of putative $S$. salmonis (Buchmann \& Uldal 1996) showed that $\mathrm{pH}$ conditions of 7.5 to 8.0 were optimum for population increase. Thus it is most unlikely that the $\mathrm{pH}$ of 7.7 in the anterior and middle regions were the reason for the reduced numbers of $S$. salmonis.

We are unable to confirm from our in vivo studies whether the preference of Spironucleus salmonis for the pyloric region is related to $\mathrm{pH}$. As noted above, we observed a pH range of 6.8 to 7.9 (mean 7.3) in infected fish, 6.7 to 7.8 (mean 7.2) in uninfected fish, and previous in vitro studies of putative $S$. salmonis give 7.5 to 8.0 as the optimum for population growth (Buchmann \& Uldal 1996) (see discussion below on optimum $\mathrm{pH}$ for S. salmonis). It is indeed very likely that other factors, such as bile, bacterial fauna, and nutrient content of the digesta play a key role in determining the microhabitat preference of $S$. salmonis. These other factors may be dominant, or may act in concert with $\mathrm{pH}$.

Bile enters the pyloric region via the bile duct that passes among the pyloric caecae (Willers 1991), and its concentration is expected to decrease posteriorly. In vitro studies show that bile in low concentrations (30 to $960 \mathrm{mg} \mathrm{l}^{-1}$ ) slightly enhanced propagation of putative Spironucleus salmonis (Buchmann \& Uldal 1996); however, statistical tests were not performed, so we do not know if the enhanced propagation was statistically significant. Thus, it may be expected that, in vivo, bile in the pyloric region also enhances propagation, possibly mediated by the gallic acids that emulsify fat (Steffens 1989), and/or the bile salts (Denton et al. 1974).

A further anterior-posterior gradient occurs in the bacterial fauna. There is a progressive decline in numbers of aerobic bacteria posteriorly, and anaerobes are generally restricted to the upper intestine (Austin \& AlZahrani 1988). We suggest that the bacterial milieu of the pyloric region may be more favourable for Spironucleus salmonis than that of more posterior regions. Although the way in which bacteria may affect the trophozoites is not known, we suggest the mechanism is indirect (perhaps via microbial digestion), since bacteria have not been reported to attach to or lie within the cytoplasm of $S$. salmonis (Poynton et al. 2004, Fard et al. 2007).

The nutrient content of the digesta decreases posteriorly, a further factor correlated with distribution of Spironucleus salmonis. In the most posterior parts of the intestinal tract, digestive and absorptive functions are diminished (Smith 1989); thus, there may not be adequate nutrients for the diplomonads.

In Spironucleus salmonis, we have shown that while the presence of infection reflects tolerable $\mathrm{pH}$, density of infection is not closely related to $\mathrm{pH}$, since there was no correlation between density and $\mathrm{pH}$ along the length of the intestine, and thus a causal relationship is unlikely. 


\section{Optimum pH for Spironucleus salmonis}

Our in vivo studies indicate that the optimum $\mathrm{pH}$ for Spironucleus salmonis may be 7.3 , since this was the mean $\mathrm{pH}$ in the pyloric region where the diplomonads were concentrated. Our determination of $\mathrm{pH}$ was accurate to within 0.2 . Therefore, we can state that, while our in vivo data suggests an optimum $\mathrm{pH}$ for $S$. salmonis of 7.3 , the optimum may lie within the range of 7.1 to 7.5 .

Our in vivo result contrasts with the results from in vitro studies for putative Spironucleus salmonis by Buchmann \& Uldal (1996), who reported a pH optimum of 7.5 to 8.0 , based on highest population density. If we assume that the same species of diplomonad was investigated in our in vivo study and in the previous in vitro study (Buchmann \& Uldal 1996), how might these apparently different optima be explained? In principle, it is likely that the $\mathrm{pH}$ recorded in vivo is closer to the optimum than that determined from culture, since in vitro conditions represent a compromised environment for trophozoites. It is also possible that the parasites we studied from rainbow trout in Germany are a different sub-species or strain from that studied by Buchmann \& Uldal (1996) from rainbow trout in Denmark. Do different sub-species or strains, if they exist, have different $\mathrm{pH}$ optima?

The suitability of $\mathrm{pH} 7.3$ for Spironucleus salmonis has not previously been determined. The results of an in vitro investigation of putative $S$. salmonis by Buchmann \& Uldal (1996) appeared to exclude $\mathrm{pH}$ conditions between 7.0 and 7.5. Moreover, it is not known whether $\mathrm{pH} 7.5$ or 8.0 was more favourable for growth, since pooled data was presented. Additional support for a true optimum $\mathrm{pH}$ being lower than 7.5 to 8.0 comes from our colleague's in vitro studies, where cultures at $\mathrm{pH} 7.0$ to 7.5 were more successful than those at pH 7.5 to 8.0 (Cheng 2006). However, caution should be exercised when comparing results of our in vitro cultures with those of Buchmann \& Uldal (1996), since as mentioned, they may have contained different subspecies or strains of $S$. salmonis, and furthermore, the culture conditions were not identical. Since our in vitro studies were targeted at yielding stock cultures for immunology experiments, we did not determine optimum $\mathrm{pH}$.

\section{Size of fish and infection}

Our finding that there were no significant differences in total length or weight of uninfected and infected juvenile rainbow trout (mean total length $12.7 \mathrm{~cm}$ ) contrasts with the significant weight reduction reported for infected rainbow trout fry (mean total length $5.5 \mathrm{~cm}$ ) by Uldal \& Buchmann (1996).
As discussed earlier, we have also noted that in our juvenile fish, occurrence and density were significantly higher in the pyloric region than elsewhere, whereas in fry there were no significant differences between pyloric and anterior regions (Uldal \& Buchmann 1996). These differences demonstrate that the nature of Oncorhynchus mykiss - Spironucleus salmonis relationship is dependant upon the size of the fish. We suggest that key factors are development of immunity (affecting the consequences of the infection, with acquired immunity developing in the juvenile fish and allowing them to cope more successfully with the infection), and development of the gut (affecting the distribution of the flagellates).

\section{Recommendations}

A number of questions about the factors determining microhabitat preference of Spironucleus salmonis remain unresolved, and we now offer recommendations for further studies to refine and extend the approach that we have presented. Refinements should include (1) standardizing the intervals between collection from the farm and examination, and between feeding and examination, thus minimizing effects of stress and changes in $\mathrm{pH}$ respectively; (2) recording density quantitatively (actual numbers of flagellates), by slowing or stopping movement of the active flagellates, via photography or adding formalin to the preparation; and (3) using microelectrodes to measure luminal pH (Brune \& Kühl 1996), and placing them precisely in the posterior region in order to measure $\mathrm{pH}$ in the rectum only (posterior to the annulo-spiral septa). Since age can be expected to have a marked impact on development of the gut, and hence the environment for the diplomonads, we also recommend that future studies should extend our present work on juvenile rainbow trout by comparing $\mathrm{pH}$ and microhabitat preference of $S$. salmonis in both fingerlings and sub-adults.

Extension of the present approach should include (4) investigating the $\mathrm{pH}$ preference of Spironucleus salmonis by exposing organisms in culture to $\mathrm{pH}$ gradients, and documenting their speed and direction of movement, and (5) ascertaining the importance of bile for growth of $S$. salmonis, which can be addressed by measurement of bile concentration in vivo, and additional in vitro studies with statistical treatment of data. Successful determination of optimum $\mathrm{pH}$ and bile requirements will enhance the efficiency of routine in vitro culture of $S$. salmonis.

In a broad sense, knowledge of Spironucleus salmonis microhabitat preference and determining factors may play a key role in predicting the likely impact of 
changes in diet on density of diplomomads. In recent years, there have been increasing efforts made to develop diets for carnivorous fish, such as trout, that have increasing amounts of plant protein, since fish meal production is stagnant or decreasing (Cheng et al. 2003). It may be expected that such changes in diet will bring about changes in the intestinal milieu within which the diplomonads live. Improved understanding of the environmental requirements of $S$. salmonis will help predict whether changes in diet may result in increased densities of the diplomonads, which may be pathogenic in young fish.

Acknowledgements. We thank M. Kunow for assistance with collecting rainbow trout from the farms and maintaining them at the Leibniz-Institute of Freshwater Ecology and Inland Fisheries, Berlin (IGB). We thank M. Sieber and U. Hentschel of the Leibniz-Institute of Freshwater Ecology and Inland Fisheries, Berlin, and C. Rada of the Department of Molecular and Comparative Pathobiology, Johns Hopkins University School of Medicine, Baltimore, for obtaining literature for us. Our gratitude is extended to W.-C. Lewin from IGB for his help with the statistical tests. We are grateful individually to E. Sterud from the National Veterinary Institute in Oslo, Norway, and K. Knopf from IGB for reviewing the paper prior to submission, to W. Kloas, and F. Kirschbaum from IGB for their financial and logistical support. We gratefully acknowledge the Nachwuchsförderungsprogramm des Landes Berlin (NaFöG) for the award of a PhD scholarship to M.R.S.F., the Amt für Ausbildungsförderung for Bafög to C.W., and the Deutsche Forschungsgemeinschaft for the award of a Mercator Visiting Professorship to S.L.P.

\section{LITERATURE CITED}

Anderson BG, Mitchum DM (1974) Atlas of trout histology. Wyoming Game and Fish Department, Cheyenne, WY

Austin B, Al-Zahrani AMJ (1988) The effect of antimicrobial compounds on the gastrointestinal microflora of rainbow trout, Salmo gairdneri Richardson. J Fish Biol 33:1-14

Brune A, Kühl M (1996) pH profiles of the extremely alkaline hindguts of soil-feeding termites (Isoptera:Termitidae) determined with microelectrodes. J Insect Physiol 42: 1121-1127

Buchmann K, Uldal A (1996) Temperature, pH and bile dependent in vitro cultivation of Hexamita salmonis from rainbow trout Oncorhynchus mykiss intestine. Dis Aquat Org 24:169-172

Cheng J (2006) Development of a modified plasma incubation test for detecting susceptibility to the piscine diplomonad Spironucleus salmonis. MSc thesis, Humboldt University, Berlin

Cheng ZJ, Hardy RW, Usry JL (2003) Effects of lysine supplementation in plant protein-based diets on the performance of rainbow trout (Oncorhynchus mykiss) and apparent digestibility coefficients of nutrients. Aquaculture 215: 255-265

Davis HS (1926) Octomitus salmonis, a parasitic flagellate of trout. Bull US Bur Fish 42:9-26

Deguara S, Jauncey K, Agius C (2003) Enzyme activities and $\mathrm{pH}$ variations in the digestive tract of gilthead sea bream. J Fish Biol 62:1033-1043
Denton JE, Yousef MK, Yousef IM, Kuksis A (1974) Bile acid composition of rainbow trout, Salmo gairdneri. Lipids 9: 945-951

Ezeasor PN, Stokoe WM (1980) Scanning electron microscopic study of the gut mucosa of the rainbow trout Salmo gairdneri Richardson. J Fish Biol 17:529-539

Fard MRS, Jørgensen A, Sterud E, Bleiss W, Poynton SL (2007) Ultrastructure and molecular diagnosis of Spironucleus salmonis (Diplomonadida) from rainbow trout Oncorhynchus mykiss in Germany. Dis Aquat Org 75: $37-50$

Ferguson HW (1979) Scanning and transmission electron microscopical observation on Hexamita salmonis (Moore, 1922) related to mortalities in rainbow trout fry Salmo gairdneri Richardson. J Fish Dis 2:57-67

Jørgensen A, Sterud E (2006) The marine pathogenic genotype of Spironucleus barkhanus from farmed salmonids redescribed as Spironucleus salmonicida n. sp. J Eukaryot Microbiol 53:531-541

Kent ML, Ellis J, Fournie JW, Dawe SC, Bagshaw JW, Whitaker DJ (1992) Systemic hexamitid (Protozoa: Diplomonadida) infection in seawater pen-reared Chinook salmon Oncorhynchus tshawytscha. Dis Aquat Org 14:81-89

Maier KJ, Tullis RE (1984) The effects of diet and digestive cycle on the gastrointestinal tract $\mathrm{pH}$ values in the goldfish Carassius auratus L., Mozambique tilapia Oreochromis mossambicus (Peters), and channel catfish Ichtalurus punctatus (Rafinesque). J Fish Biol 25:151-165

Moore E (1922a) Description of Octomitus salmonis. NY State Conserv Comm Annu Rep 12:69-76

Moore E (1922b) Octomitus salmonis, a new species of intestinal parasite in trout. Trans Am Fish Soc 52:74-97

Page JW, Andrews JW, Murai T, Murray MW (1976) Hydrogen ion concentration in the gastrointestinal tract of channel catfish. J Fish Biol 8:225-228

Paull RA, Matthews GC (2001) Spironucleus vortens, a possible cause of hole-in-the-head disease in cichlids. Dis Aquat Org 45:197-202

Poynton SL, Morrison CM (1990) Morphology of diplomonad flagellates: Spironucleus torosa n. sp. from Atlantic cod Gadus morhua L., and haddock Melanogrammus aeglefinus (L.) and Hexamita salmonis Moore from brook trout Salvelinus fontinalis (Mitchill). J Protozool 37:369-383

Poynton SL, Fraser W, Francis-Floyd R, Rutledge P, Reed P, Nerad TA (1995) Spironucleus vortens n. sp. from freshwater angelfish Pterophyllum scalare: morphology and culture. J Eukaryot Microbiol 42:731-742

Poynton SL, Fard MRS, Jenkins J, Ferguson HW (2004) Ultrastructure of Spironucleus salmonis n. comb. (formerly Octomitus salmonis sensu Moore 1922, Davis 1926, and Hexamita salmonis sensu Ferguson 1979), with a guide to Spironucleus species. Dis Aquat Org 60:49-64

Saghari Fard MR (2001) Ecology, host-parasite interaction, and ultrastructure of diplomonad flagellates in commercially important fish species. MSc thesis, Humboldt University, Berlin

Smith LS (1989) Digestive function in teleost fishes. In: Halver JE (ed) Fish nutrition, 2nd edn. Academic Press, London, p 332-421

Steffens W (1989) Principles of fish nutrition. Ellis Horwood, Chichester

Sterud E (1998a) Electron microscopical identification of the flagellate Spironucleus torosa (Hexamitidae) from burbot Lota lota (Gadidae) with comments upon its probable introduction to this freshwater host. J Parasitol 84: 947-953 
Sterud E (1998b) Ultrastructure of Spironucleus torosa Poynton \& Morrison, 1990 (Diplomonadida: Hexamitidae), in cod Gadus morhua (L.) and saithe Pollachius virens (L.) from south-eastern Norway. Eur J Protistol 34: 69-77

Sterud E, Mo TA, Poppe, TT (1997) Ultrastructure of Spironucleus barkhanus n. sp. (Diplomonadida: Hexamitidae) from grayling Thymallus thymallus (L.) (Salmonidae) and Atlantic salmon Salmo salar L. (Salmonidae). J Eukaryot Microbiol 44:399-407

Sterud E, Mo TA, Poppe, TT (1998) Systemic spironucleosis in sea-farmed Atlantic salmon Salmo salar, caused by Spironucleus barkhanus transmitted from feral Arctic char Salvelinus alpinus? Dis Aquat Org 33:63-66

Sterud E, Poppe TT, Bornø G (2003) Intracellular infection

Editorial responsibility: Dieter Steinhagen,

Hannover, Germany with Spironucleus barkhanus (Diplomonadida: Hexamitidae) in farmed Arctic char Salvelinus alpinus. Dis Aquat Org 56:155-161

Uldal A, Buchmann K (1996) Parasite host-relations: Hexamita salmonis in rainbow trout Oncorhynchus mykiss. Dis Aquat Org 25:229-231

Weinreb EL, Bilstad NM (1955) Histology of the digestive tract and adjacent structures of the rainbow trout, Salmo gairdneri irideus. Copeia 3:194-204

Willers B (1991) Trout biology. Lyons \& Burford, New York

Woo PTK, Poynton SL (1995) Diplomonadida, Kinetoplastida and Amoebida (Phylum Sarcomastigophora). In: Woo PTK (ed) Fish diseases and disorders, Vol 1, Protozoan and metazoan disorders. CAB International, Wallingford, p 27-96

Submitted: January 4, 2007; Accepted: May 2, 2007 Proofs received from author(s): July 3, 2007 